\title{
New size record of the lollipop shark Cephalurus cephalus caught offshore Bahía Magdalena, Mexico
}

\author{
Mario Jaime-Rivera ${ }^{1}$, Roberto Carlos López-Archundia ${ }^{2}$ \& Cesar Augusto Salinas-Zavala ${ }^{3}$ \\ ${ }^{1}$ Departamento de Biología Marina, Universidad Autónoma de Baja California Sur \\ La Paz, B.C.S., México \\ ${ }^{2}$ Instituto Politécnico Nacional, Centro Interdisciplinario de Ciencias Marinas (CICIMAR) \\ La Paz, B.C.S., México \\ ${ }^{3}$ Centro de Investigaciones Biológicas del Noroeste (CIBNOR), La Paz, B.C.S., México \\ Corresponding author: Mario Jaime-Rivera (carcharodonmaritus@yahoo.com.mx)
}

\begin{abstract}
A new size record of the lollipop shark Cephalurus cephalus is described. It is a $367 \mathrm{~mm}$ of total length female captured offshore Bahía Magdalena, Mexico. This is a contribution to the knowledge of rare deep-sea Chondrichthyans of demersal habits.
\end{abstract}

Keywords: Cephalurus cephalus; shark; deep-sea fauna; demersal habits; Mexico

Biology of deep-sea chondrichthyan fishes is poorly known due to its infrequent capture and low or nonexistent commercial value (Ruiz-Campos et al., 2010). One of the less studied deep-sea sharks is the lollipop catshark Cephalurus cephalus (Castro, 2010). It inhabits the eastern tropical Pacific and the Gulf of California at depths of 155 to $927 \mathrm{~m}$ (Compagno, 1984). This fish has a body like a tadpole, broadly rounded head with a trunk that narrows to the caudal fin. Its anatomy is in accord with its demersal habits (Compagno, 1984). The lollipop catshark is a placental viviparous fish. Females have two functional ovaries and retain pairs of thin-shelled egg cases until they hatch. Neonates measure about $100 \mathrm{~mm}$ of total length (TL); sexual maturation is reached at a length of $\sim 190$ $\mathrm{mm}$ TL for males and $240 \mathrm{~mm}$ TL for females (Compagno, 1984). The goal of this paper is to update the known maximum size of Cephalurus cephalus (see Compagno, 1984; Castro, 2011).

Sharks were caught incidentally during an exploring hake fishing campaign of the oceanographic vessel BIP XII of the Centro de Investigaciones Biológicas del Noroeste during July 2017. Fishing operation with trawling epibenthic nets lasted $40 \mathrm{~min}$ at a depth range of 365 m offshore Bahía Magdalena (Fig. 1).

Caught lollipop sharks were kept in ice at $-4^{\circ} \mathrm{C}$ and carried to the laboratory. In order to determine the size structure, the total length of sharks was measured. Sharks were sexed based upon its sexual dimorphism,

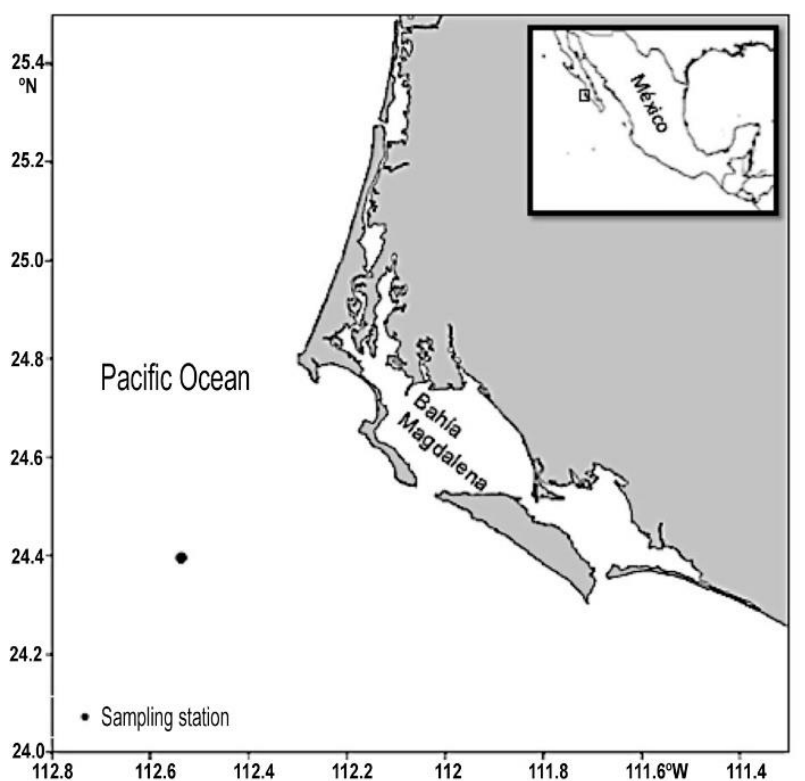

Figure 1. Location where the lollipop sharks were caught

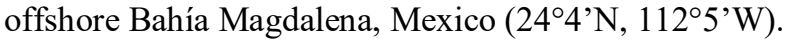

identifying the presence (length and maturation state) of claspers. A total of 309 sharks were collected; 122 were males and 187 females. Female lengths were 83$367 \mathrm{~mm}$ TL, with an average of $156 \mathrm{~mm}$ TL. Male lengths were 85-245 $\mathrm{mm}$ TL with an average of 132 $\mathrm{mm}$ TL. A singular large female measured $367 \mathrm{~mm}$ and 

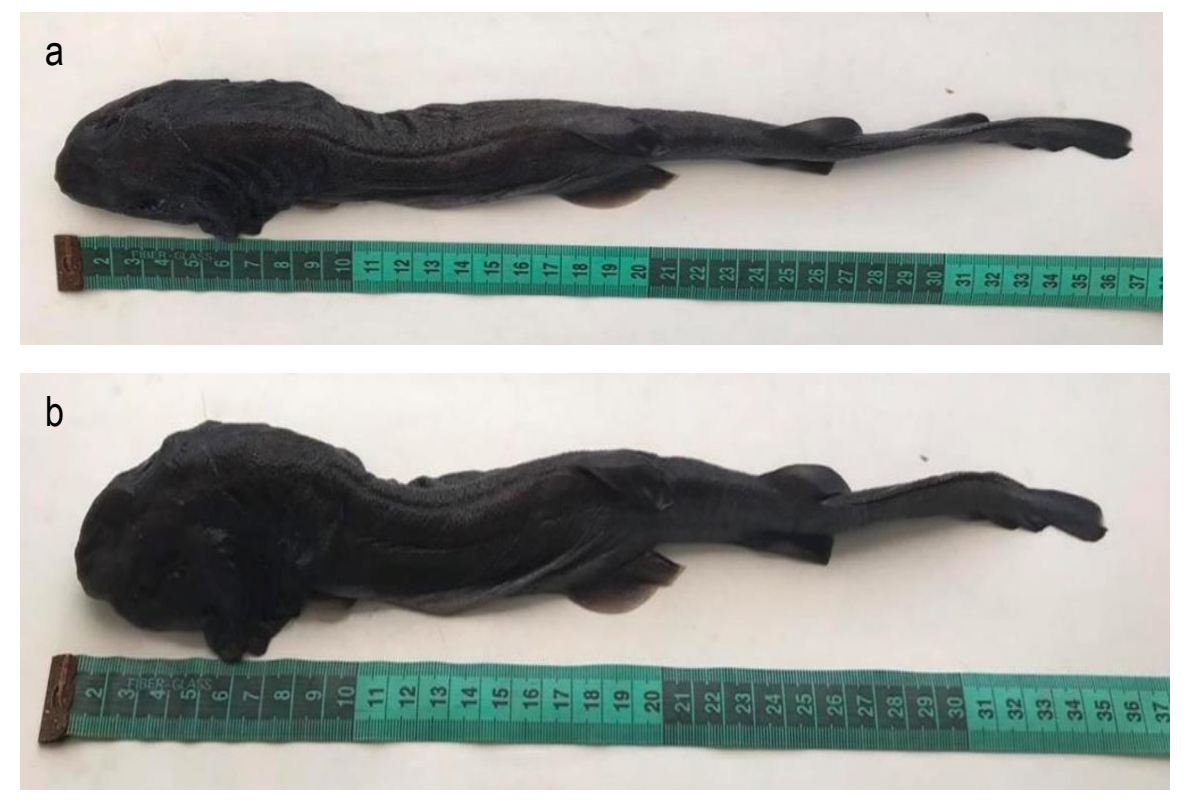

Figure 2. Female of lollipop shark Cephalurus cephalus. a) Dorsal view, b) lateral view.

Table 1. Measures for the female described of Cephalurus cephalus.

\begin{tabular}{lcc}
\hline Character & $\mathrm{mm}$ & $\% \mathrm{TL}$ \\
\hline Total length & 367 & 100 \\
Pre-caudal length & 250 & 68.1 \\
Preorbital length & 22 & 6.0 \\
Eye length & 15 & 4.1 \\
Eye height & 5 & 1.4 \\
Prenarial length & 15 & 4.1 \\
Preoral length & 20 & 5.4 \\
Tip of snout to origin of furrow above eye & 10 & 2.7 \\
Length of mouth & 34 & 9.3 \\
Width of mouth & 23 & 6.3 \\
Inter-narial space & 10 & 2.7 \\
Width of nostril & 9 & 2.5 \\
Length of anterior nasal flaps & 5 & 1.4 \\
Inter-orbital space & 27 & 7.4 \\
First dorsal height & 17 & 4.6 \\
First dorsal base & 20 & 5.4 \\
First dorsal length & 35 & 9.5 \\
Superior lobe length & 19 & 5.2 \\
Height of first gill slit & 14 & 3.8 \\
Height of fifth gill slit & 10 & 2.7 \\
\hline
\end{tabular}

weighted $194 \mathrm{~g}$ (Fig. 2). It had immature oocytes in the ovaries, there were no egg cases retained in the oviducts, the uteruses were void with no embryos, and no stomach content was found. Anatomy character measures are shown in Table 1.

Previously reported maximum TL for the species was a specimen from Chile of $320 \mathrm{~mm}$ (Compagno, 1984; Castro, 2011). Castro-Aguirre (1981) reported lengths for females and males of 295 and $245 \mathrm{~mm}$ TL, respectively. The paratype of the species was a male of $243 \mathrm{~mm}$ TL described by Gilbert (Howe \& Springer, 1993). Bigelow \& Schroeder (1941) examined and described an immature male of $186 \mathrm{~mm}$ TL while established the genus Cephalurus for this species. Maximum lengths recorded by scarce registers are shown in Table 2. The lack of embryos and egg cases suggest that the female could undergo a reproductive event. Hatching occurs from summer to winter with no 
Table 2. Maximum lengths recorded for Cephalurus cephalus. M: male, F: female, ns: not specified.

\begin{tabular}{llcl}
\hline $\begin{array}{l}\text { Reported maximum } \\
\text { size }(\mathrm{mm})\end{array}$ & Location & $\begin{array}{c}\text { Depth } \\
(\mathrm{m})\end{array}$ & Reference \\
\hline $186(\mathrm{M})$ & Gulf of California & 662 & Bigelow \& Schroeder (1941) \\
$243(\mathrm{M})$ & Islas Revillagigedo & 841 & Gilbert (1892) cited by Howe \& Springer (1993) \\
$243(\mathrm{~F}), 257(\mathrm{M})$ & Gulf of California & $464-486$ & Aguirre-Villaseñor \& Salas-Singh (2012) \\
$264(\mathrm{~ns})$ & Gulf of California & $341-500$ & Mathews \& Ruiz (1974) \\
$295(\mathrm{~F}), 245(\mathrm{M})$ & Western coast of Baja California Sur & $112-508$ & Castro-Aguirre (1981) \\
$295(\mathrm{~F}), 298(\mathrm{M})$ & Western coast of Baja California Sur & $230-280$ & Balart et al. (2000) \\
$320(\mathrm{~F})$ & Chile & $\mathrm{ns}$ & Compagno (1984); Castro (2011) \\
$367(\mathrm{~F}), 245(\mathrm{M})$ & Western coast of Baja California Sur & $358-365$ & This study \\
\hline
\end{tabular}

defined breeding season (Balart et al., 2000; AguirreVillaseñor \& Salas-Singh, 2012).

A new size record of this cryptic shark that expands knowledge of deep-sea chondrichthyan fishes, and a new record for the species is herein reported. Data concerning the biology of Cephalurus cephalus are deficient (Valenti, 2009). The importance of catching this species as an incidental catch regards in the improvement of the knowledge about its population trend and conservation status.

\section{ACKNOWLEDGMENTS}

We wish to thank Fernando Manini for the facilities in the ship. Funding was provided by the Project "Transferencia de paquete tecnológico para la merluza, Merluccius productos en la costa occidental de la Península de Baja California, México" Centro de Investigaciones Biológicas del Noroeste (CIBNOR) and CONACYT.

\section{REFERENCES}

Aguirre-Villaseñor, H. \& Salas-Singh, C. 2012. New records of the lollipop catshark Cephalurus cephalus (Scyliorhinidae) from the Gulf of California, Mexico. Revista Mexicana de Biodiversidad, 83(1): 298-300.

Balart, E.F., González-García, J. \& Villavicencio-Garayzar, C. 2000. Notes on the biology of Cephalurus cephalus and Parmaturus xaniurus (Chondrichthyes: Scyliorhinidae) from the west coast of Baja California Sur, México. Fishery Bulletin, 98: 219-221.

Received: 9 January 2019; Accepted: 10 April 2019
Bigelow, H.B. \& Schroeder, W.C. 1941. Cephalurus, a new genus of scyliorhinid shark with redescription of the genotype, Catulus cephalus Gilbert. Copeia, 2: 7376.

Castro, J.I. 2011. The sharks of North America. Oxford University Press, Oxford.

Castro-Aguirre, J.L. 1981. Especies de la familia Scyliorhinidae (Elasmobranchii, Galeoidea), de la costa occidental de México, con especial referencia a Cephalurus cephalus (Gilbert). Anales de la Escuela Nacional de Ciencias Biológicas, México, 24: 71-93.

Compagno, L.J.V. 1984. Sharks of the world: an annotated and illustrated catalogue of shark species known to date. FAO, Rome, pp. 305-306.

Howe, J.C. \& Springer, V.G. 1993. Catalog of type specimens of recent fishes in the National Museum of Natural History, Smithsonian Institution, 5: Sharks (Chondrichthyes: Selachii). Smithsonian Contributions to Zoology, 540: 19 pp.

Mathews, C.P. \& Ruiz, D. 1974. Cephalurus cephalus, a small shark, taken in the northern Gulf of California, with a description. Copeia, 2: 556-560.

Ruiz-Campos, G., Castro-Aguirre, J.L., Balart, E.F., Campos-Dávila, L. \& Vélez-Marín, R. 2010. New specimens and records of chondrichthyan fishes (Vertebrata: Chondrichthyes) off the Mexican Pacific coast. Revista Mexicana de Biodiversidad, 81(2), 363371.

Valenti, S.V. 2009. Cephalurus cephalus. The IUCN Red List of Threatened Species: e.T161455A5428230. 